\title{
Phenotypic Characterization and Distribution of SenSi-1 Agrinak Chicken
}

\section{(Karakterisasi Fenotipik dan Penyebaran Ayam SenSi-1 Agrinak)}

\author{
Sofjan Iskandar \\ Indonesia Research Institute for Animal Production (IRIAP), PO Box 221, Bogor 16720 Indonesia \\ sofjaniskandar@yahoo.com
}

(Diterima 2 Januari 2018 - Direvisi 28 Mei 2018 - Disetujui 5 Juni 2018)

\begin{abstract}
The utilization of local chicken genetic resources in Indonesia is increasing after the government program to achieve food sovereignty including livestock products. In the year of 2017, the Indonesian Research Institute for Animal Production (IRIAP) released SenSi-1 Agrinak chicken breed to be used as commercial meat type of local chicken in Indonesia. This paper describes development and distribution of the SenSi-1 Agrinak. This breed was selected from the native breed of Sentul chicken, originated from Ciamis District of West Java Province. The Sentul male was selected to achieve average live weight of $1 \mathrm{~kg} / \mathrm{bird}$ at 10 weeks of age, with grey (G) and black spotted white (BSW) plumage color and pea-comb type. After six generations of selection, SenSi-1 Agrinak was released as an improved local meat-type chicken breed. License to private local chicken breeders is expected to increase SenSi-1 Agrinak population and distribution. Collaboration with several Assessment Institutes for Agricultural Technology (AIAT) and implementation of BEKERJA-Ministry of Agriculture program can accelerate population and distribution of SenSi-1 Agrinak chicken to farmers throughout Indonesia.
\end{abstract}

Key words: SenSi-1 Agrinak chicken, selection, production, distribution

\begin{abstract}
ABSTRAK
Pemanfaatan sumber daya genetik ayam lokal di Indonesia meningkat setelah adanya program pemerintah untuk mencapai kedaulatan pangan termasuk produk ternak. Pada tahun 2017 Balai Penelitian Ternak (Balitnak) telah melepas galur ayam SenSi1 Agrinak sebagai salah satu galur unggul ayam pedaging lokal. Tujuan dari makalah ini adalah untuk menginformasikan pengembangan dan penyebaran ayam SenSi-1 Agrinak kepada masyarakat. Galur ayam SenSi-1 Agrinak diseleksi dari rumpun ayam Sentul yang berasal dari Kabupaten Ciamis, Provinsi Jawa Barat. Ayam Sentul jantan diseleksi untuk mencapai bobot tubuh rata-rata $1 \mathrm{~kg} /$ ekor dengan warna bulu abu dan pucak (putih bercak hitam), serta berjengger kacang. SenSi-1 Agrinak dihasilkan dari proses seleksi selama enam generasi dan dilepas sebagai ayam lokal pedaging unggul. Pemberian lisensi kepada perusahaan perbanyakan bibit swasta diharapkan dapat meningkatkan populasi dan distribusinya. Kerjasama dengan Balai Pengkajian Teknologi Pertanian (BPTP) dan melalui program BEKERJA Kementerian Pertanian, dapat mempercepat peningkatan populasi dan distribusi ayam SenSi-1 Agrinak ke seluruh peternak pengguna di Indonesia.
\end{abstract}

Kata kunci: Ayam SenSi-1 Agrinak, seleksi, produksi, distribusi

\section{INTRODUCTION}

In the middle of an era of commercial chicken industry in Indonesia, which is dominated by imported grand parent or parent stocks, the local chicken industry has also been lifted. The name of kampung chicken in Indonesia has been popular as a commercial icon, although in the recent days, the name of kampung chicken seemed to be criticized after recognizing that the name kampung chicken is taken from the name of one of the native breeds existing in Indonesia (Sartika $\&$ Iskandar 2007). There are more than 30 local-breeds claimed in Indonesia, which several of them have been genetically improved for the commercial commodity in Indonesian chicken industry (Sartika et al. 2017). Local chicken however, has been contributing to national meat production of about $8.50 \%$ or about 284.9 thousand tons or about $12.86 \%$ contribution to the whole national chicken meat production (Dirjen PKH 2017).

Sentul-chicken is one of the Indonesian native chicken breeds and has been known in Eastern of West Java Province. It is a specific kind of local chicken as egg and meat type. Hidayat \& Sopiyana (2010) recognized that Sentul chicken, which is an Indonesian animal-genetic resource, had a promising potential resource to be a commercial commodity.

Inspiring by FAO's the state of the world animal genetic resources for food and agriculture (FAO 2007) and excellent suggestion in implementing of action for animal genetic resources by Hoffmann \& Scherf (2010), the Indonesian Agency for Agricultural 
Research and Development (IAARD) through the Indonesian Research Institute for Animal Production (IRIAP) has taken an action to explore local chickens in Indonesia. Eventually, the Sentul chicken was chosen as local breeds to be preserved and improved to support the national local-chicken industry.

The IRIAP has initiated selection for a uniform breed of local chicken. The breed of SenSi-1 Agrinak chicken was the second breed of two breeds that were selected for meat type. The Sentul breed was then chosen to be selected for improved live weight (an average of $1 \mathrm{~kg} / \mathrm{bird}$ ) at 10 weeks old as preferred by market (Wibowo \& Sartika 2011; Sejati \& Saptana 2013; Rasyid \& Kasim 2014). In addition to the specific mark of the breed, the uniform plumage color and the comb type of males were taken into consideration.

The aim of the paper is to inform how the SenSi-1 Agrinak breed was developed and efforts to disseminate and to distribute the breed to the users.

\section{THE ORIGIN OF SENTUL CHICKEN}

Ciamis is an autonomy district in West Jawa Province. Ciamis area is in the Eastern-South of West Java area (Figure 1). The community in Ciamis area mostly inhabited with Sundanese ethnic, keeping Sentul chicken for their own home purposes. The community recognizes the chicken as kulawu (grey plumage) chicken, which is different from kampung chicken, which varies in plumage color, comb type, shank color, and body shape (Sulandari et al. 2007; Hidayat \& Sopiyana 2010).

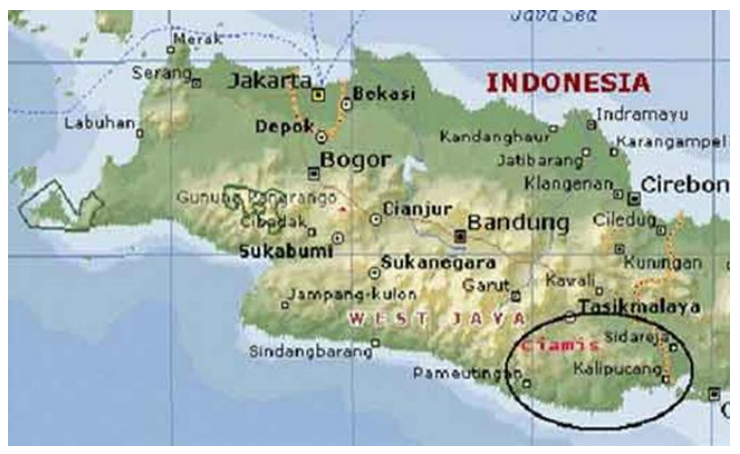

Figure 1. The location of Ciamis District, West Jawa Province (inside the circle)

Source: https://www.google.com/maps/@-6.8246595,107.5 $256883,8 \mathrm{z}$

Since year 2004, the Ciamis District of Animal Husbandry Services (DAHS) has tried to promote the existence of Sentul chicken to the community through variety of means, such as body-appearance contest and distribution the chicken to the wider area in Ciamis
District (Hidayat \& Sopiyana 2010). Ciamis DAHS has started to carry out the preservation program of Sentul chicken through establishment of a small breeding unit for Sentul chicken under the management of Ciamis DAHS District (Suherman 2015).

Back to the time whether the Sentul chicken was really origin Java or not, Sawai et al. (2010) reported that four species of genus Gallus inhabited Southeast Asia, they were red jungle fowl (Gallus g. gallus), La Fayette's jungle fowl (Gallus lafayette), grey jungle fowl (Gallus sonnerati), and green jungle fowl (Gallus various). Grey jungle fowl, which has body plumage of a grey background color, is distributed spread out from Southwest to Central India. While morphologically distinct of green jungle fowl was limited to Java and its immediate vicinity, Bali and Lombok. Red jungle fowl (Gallus gallusbankiva) was found in Indonesia spread out throughout South Sumatra, Java, Bali, and Gallus gallusspadiceus was spread out from the area of North Sumatra to Southeast Asia (Sulandari et al. 2007).

\section{CHARACTERISTIC OF SENTUL CHICKEN}

\section{Original plumage}

Sentul chicken has specific plumage of grey color, covering the body surface and/or underneath the prime feather (Sulandari et al. 2007). Although to some extent, the plumage of body surface appears yellow, red or light grey, especially the roosters; they have more colorful plumage than the females do. The body shape of the rooster is more like a medium fighting cock with pea type of comb.

The appearance of adult Sentul chicken which was observed from their limited habitat area in Ciamis District (Hidayat \& Sopiyana 2010), with varying in plumage color are presented in Figure 2 (the modified photograph from another version collected by Iskandar). Its variation has a name, taken from the color of the plumage, i.e. dark-grey, light-grey, grey, golden, red, and brown plumage. There were six plumage colors identified, but there were no data explaining how much population in each plumage color.

Sartika et al. (2010) reported that the frequency of gen controlling the phenotype characteristics of Sentul chicken, which were raised in the IRIAP facilities (Table 1), revealed that the bird phenotype based on external genetic is not categorized in plumage pattern according to Nishida et al. (1982), as it has genotype ii (colored) of $100 \%$. The basic plumage color of Sentul chicken quite varies from dark to brownish.

Feather sparkling and barring, shank color and comb type vary as it were found in general local chicken. Gen frequency of feather silverish sparkling, 


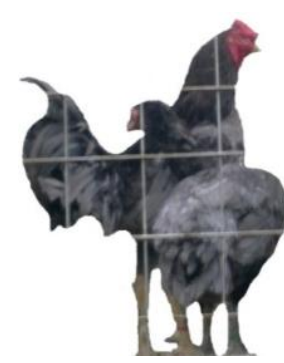

Dark-grey Sentul

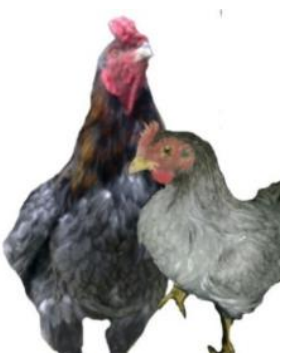

Grey Sentul

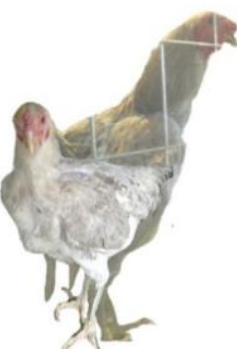

Light-grey Sentul

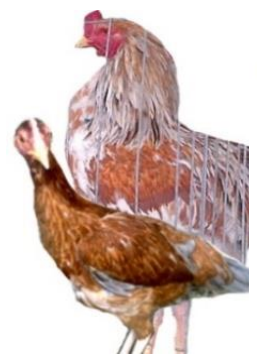

Red Sentul

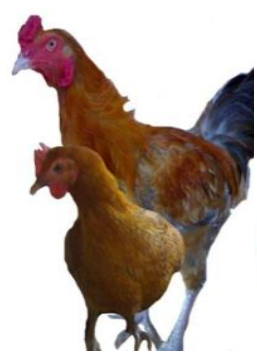

Golden Sentul

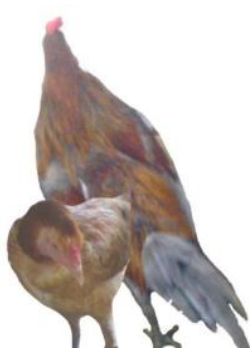

Brown Sentul

Figure 2. Plumage color in Sentul chicken found in Ciamis District

Source: Iskandar's collection

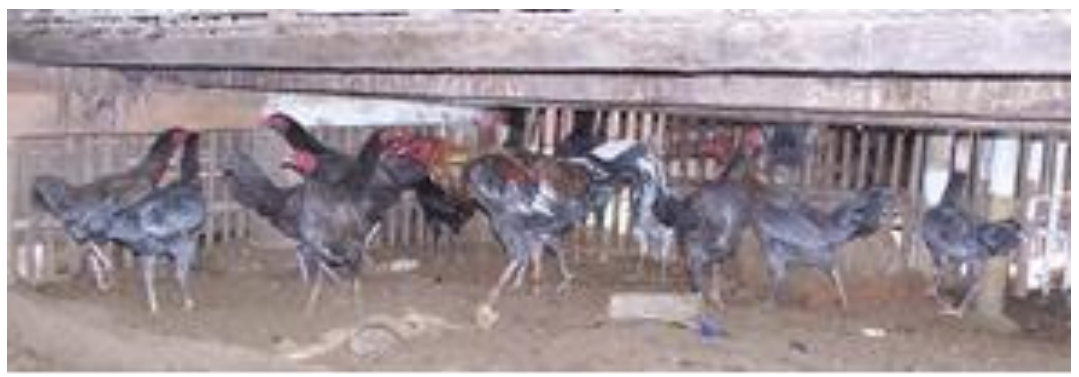

Figure 3. Sentul chicken owned by a villager in Ciamis District

Source: Iskandar's collection

Table 1. The frequency of controlling gen on the external chracteristics of Sentul chicken

\begin{tabular}{|c|c|c|c|c|}
\hline Characteristics & Locus & Gen & Genotype/phenotype & Gen frequency $(\%)$ \\
\hline \multirow[t]{2}{*}{ Plumage color } & $\mathrm{I}-\mathrm{i}$ & $q^{I}$ & I- ( white) & 0 \\
\hline & & $q^{i}$ & ii (colored) & 100 \\
\hline \multirow[t]{4}{*}{ Plumage pattern } & $E-e^{+}-e$ & $q^{\mathrm{E}}$ & E- (black) & 0 \\
\hline & & $\mathrm{q}^{\mathrm{e}+}$ & $\mathrm{e}^{+}-($wild type $)$ & 0 \\
\hline & & $q^{e}$ & ee (columbian) & 0 \\
\hline & & & others & 100 \\
\hline \multirow[t]{2}{*}{ Feather sparkling } & S-s & $q^{s}$ & S- (silverish) & 88.24 \\
\hline & & $q^{s}$ & ss (goldish) & 11.76 \\
\hline \multirow[t]{2}{*}{ Feather barring } & B-b & $q^{B}$ & B- (barred) & 9.80 \\
\hline & (sex linked) & $\mathrm{q}^{\mathrm{b}}$ & bb (non-barred) & 90.2 \\
\hline \multirow[t]{2}{*}{ Shank color } & Id- id & $\mathrm{q}^{\text {Id }}$ & Id- (yellow/white) & 37.25 \\
\hline & & $q^{\text {id }}$ & idid (black, grey, greenish) & 62.75 \\
\hline \multirow[t]{2}{*}{ Comb type } & P-p & $\mathrm{q}^{\mathrm{P}}$ & P- (pea) & 50.98 \\
\hline & & $\mathrm{q}^{\mathrm{p}}$ & pp (single) & 49.02 \\
\hline
\end{tabular}

Source: Sartika et al. (2010)

non-barred with black or grey shank color of Sentul chicken were high, whilst comb type of pea and single types was in about 50:50. Recently, Hirst (2017) mentioned that although the history of the chickens (Gallus domesticus) was first domesticated from red jungle fowl (G. gallus) in Southeast Asia, this bird was most likely hybridized with grey jungle fowl ( $G$. sonneratii). So, this can be used the indication in the Sentul chicken by having the variation in their plumage color. Even today, we still cannot clearly see if the Sentul came from the single ancestor, as it was recognized by Morejohn (1968) that they could not 


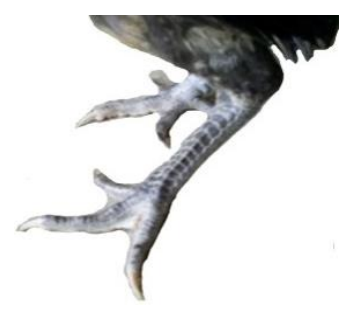

Black shank

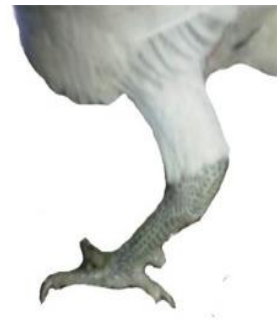

Grey shank

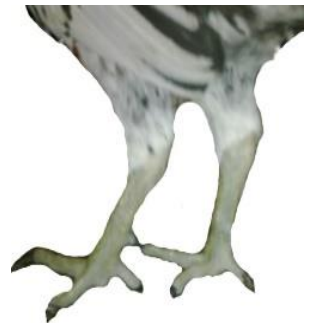

Green shank

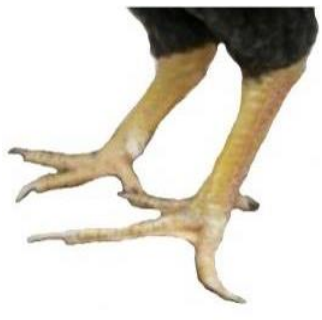

Yellow shank

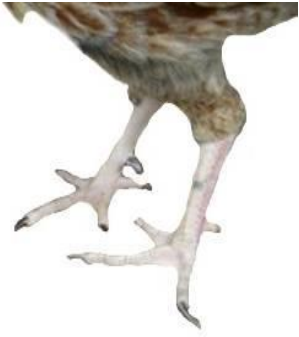

White shank

Figure 4. Shank-color of Sentul chicken

Source: Iskandar's collection

differentiate whether it had monophyletic origin from one of the wild species or polyphyletic origin from two or more of the living four species ( $G$. gallus, $G$. lafayetii, G. sonneratii, and G. varius).

However, villagers in Ciamis prefered plumage having dark-grey Sentul (Figure 3) more than the other plumage color variations. Selection which was done by villagers in Ciamis District would eventually change little bit appearance of nowadays Sentul chicken to be more homogenous.

\section{Shank color of Sentul chicken}

Shank color of Sentul chicken was found out to consist of five types, which were white, yellow, green, and grey or black (Figure 4). In comparative to other countries' native-chickens, Sarker et al. (2014) reported that one of Bangladesh Desy chicken had four types of shank colors were most frequently observed, i.e. white (39.87\%), yellow (37.22\%), black (20.04\%), and mixed (2.87\%). Dana et al. (2010) reported that there were three colors of shank of Ethiopian natives chicken. Jin et al. (2016) stated that the shank-skin color traits had been used to reveal their origin of domestication or genetic relationship in chickens.

Furthermore they stated that the genetic basis of shank skin color could have significant impacts on basic skin color biology and domestic processes. In addition, the shank-skin color could often have economic values when used as an indicator for nativechicken-breed recognition since most of native-chicken had pigmented shank color. However, chickens which had their shank with light color such white and yellow would generally have their skin with light color (white or yellow) and vice versa for dark colors, but there were seemed no superiority reported in body growth of the chicken which had specific color of shank.

\section{The genetic distance of Sentul chicken}

It could be the first study of Indonesian local chicken, Nishida et al. (1988) who reported that Indonesian local chicken held about $50 \%$ local genes on the average. This can be interpreted that other $50 \%$ genes came from outside of Indonesian archipelago, either from Asia or Europe. However, it might be applied to Sentul chicken from Ciamis District as reported by Sartika et al. (2004), based on the unweighted pair-group method with arithmetic means (UPGMA) method, showed that in Sentul chicken together with Kampung, Black Kedu, and Pelung chicken did not have specific allele, which differentiated one to another breed. Furthermore, Sulandari et al. (2008) reported based on counting genetic distance using DnaSP program, that Sentul chicken paired wisely with other local chickens (Cemani, Kampung, Pelung, Black Kedu, White Kedu, and Gaok), had a close genetic distance (0.014-0.071), showed that they were from the same source of ancestor.

\section{IMPROVING THE SENTUL CHICKEN}

\section{Background of the program}

As it was driven by the increasing demand of local chicken as mentioned by Purba (2016) who also reported why the local chicken had prospectus business. Their reasons were: (1) Demand for kampung chicken meat was increasing, due to the increase of middle society in Indonesia; (2). The government had a plan to increase people animal protein consumption, through increasing local chicken production; (3) People awareness of healthy food consumption as they know that local-chicken meat was much healthier than exoticchickens; and (4) The selling price of local-chicken was much higher and stable, motivating the farmers to raise more local-chickens. The purpose of selection of Sentul chicken was aimed to some extent fulfilling the demands.

In addition, improving the productivity of local chicken must be considered carefully as it will change the quality of the meat. Several changes in meat quality have been recently reported because of the intense selection process for performance traits in broiler breeding programs (Gaya et al. 2011; de Paiva et al. 
2018). FAO (2009) reported that exotic poultry and cooled chicken meat have a bad image because people believe that they contain preservatives, antibiotics, and chemicals. However, this preservatives and growth promoters issue can be overcome by reduction of those chemicals in the feed. In addition, Jaturasitha et al. (2002) and Sarsenbek et al. (2013) mentioned that the quality of meat of native chicken was better than that of modern broilers chicken. Umaya (2014) also reported that native breeds possessed certain distinctive qualities that included high immunocompetence and better meat quality compared to commercial broiler chickens. Furthermore, by having native breeds of chicken, Indonesian consumers will have many choices for their preferences; it is not only depended on imported chicken.

\section{Research and development strategy in selecting Sentul chicken}

As it was reported by Sartika et al. (2010), that dark-grey color of the plumage seemed to dominate plumage color of the Sentul-chicken breed. The research was then continued at the station, based on this variation by selecting dark-grey and grey Sentul chicken as recognition of the population for further selection program without concerning the shank color. Although the shank-skin color could often have economic values when used as an indicator for localchicken-breed recognition since most of local-chicken had pigmented shank color (Dana et al. 2010), this matter may be the next character that should be included in the breeding program.

Research and development strategy, which has been developed in the IRIAP is presented in Figure 5.
IRIAP as a government research institute for animal production planned short-term program for selecting Sentul chicken for meat type. Based on all information, selection program was started with about 164 females grey and 54 males Sentul chicken of dark grey, grey and light grey plumage color (Iskandar et al. 2012).

The program was then initiated with mating the birds within the same plumage color of Sentul chicken resulted in the first generation with various plumage colors revealed. Iskandar et al. (2012) reported that plumage color variation of males of the first offspring consisted of $45.40 \%$ dark-grey, $38.55 \%$ black-spotted white, $8.43 \%$ black, and $3.61 \%$ brown. Whilst the females consisted of $45.19 \%$ dark grey, $35.54 \%$ blackspotted white, $10.58 \%$ black, and $7.69 \%$ brown. Comb type of most male chicken dominated by pea type $(73.21 \%)$ and the rest was single comb type of $26.79 \%$. Therefore, based on the variation of the above phenotypes, the following selection was based on the criteria of the dark-grey Sentul chicken and blackspotted white Sentul chicken, combined with pea type comb for both males of both strains (Figure 6).

According to characteristics of the first offspring reported by Iskandar et al. (2012), the selection criterias were then established to the population by selecting the top $25 \%$ live body weight at 10 weeks old of either grey or black spotted white plumage of male population with a pea comb. Whilst the females were selected for only plumage color of grey and black spotted white. The selected populations were two groups, which were grey males-female chicken, and male-female black-spotted white. Each group was mated interse and the selection was carried out up to about six years to establish products called grey (G) SenSi-1 Agrinak and black spotted white (BSW)

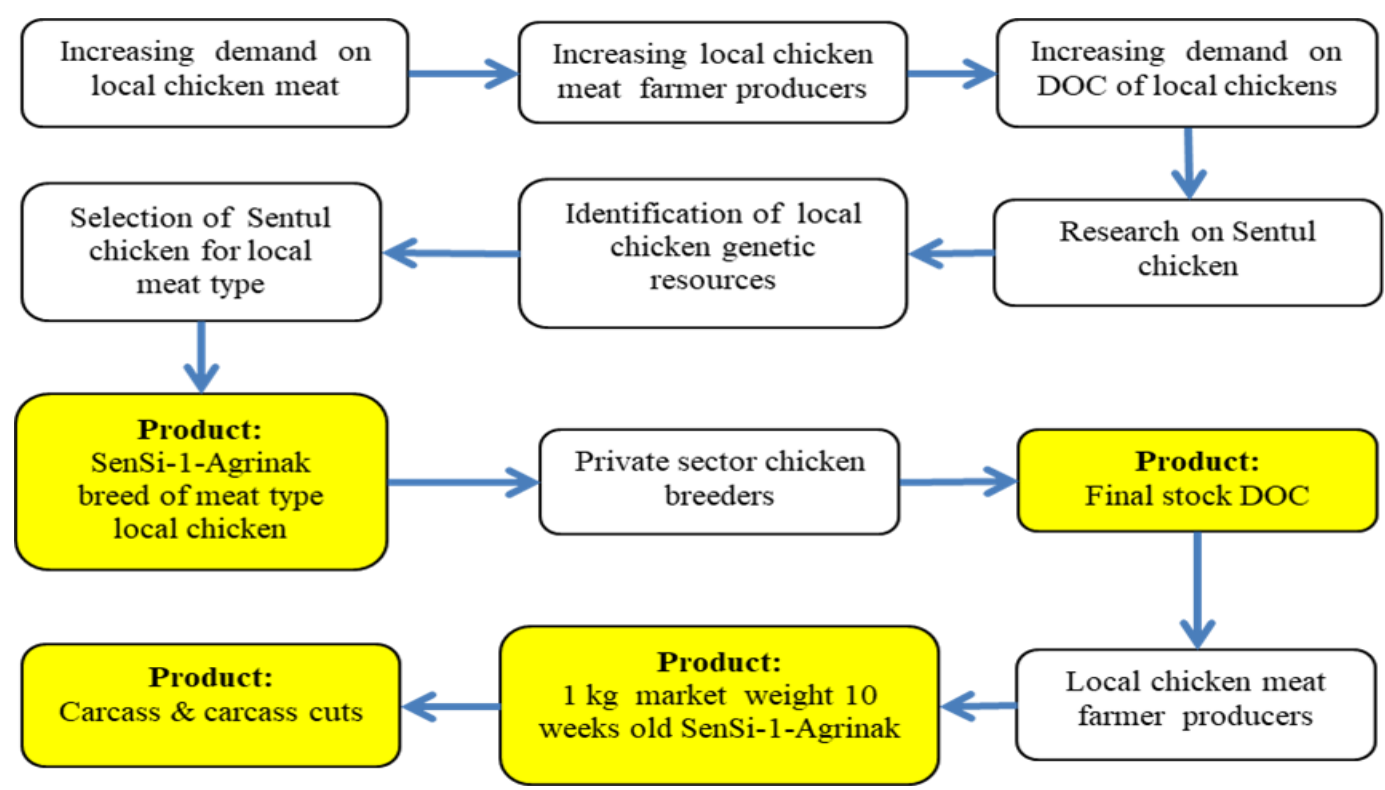

Figure 5. Research and development diagram of Sentul chicken conducted at IRIAP 

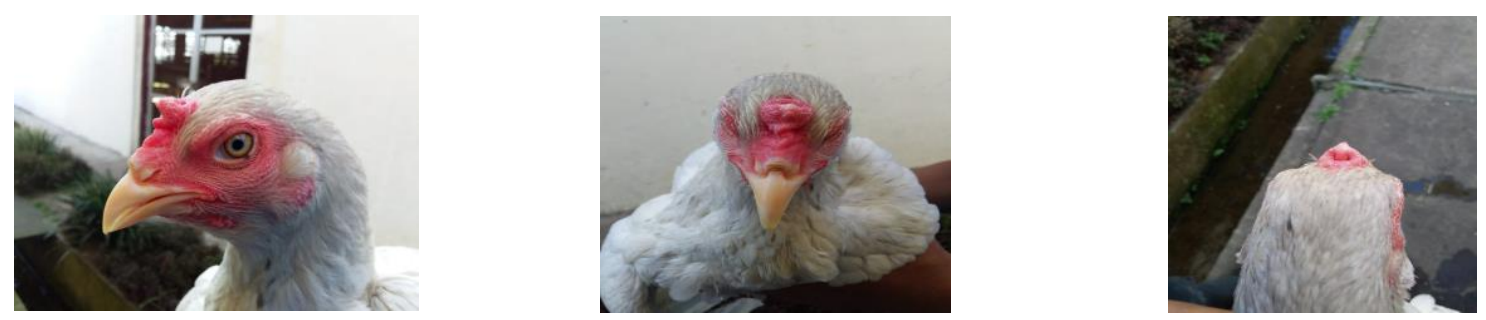

Figure 6. Pea comb type of SenSi-1 Agrinak

Source: Iskandar's collection
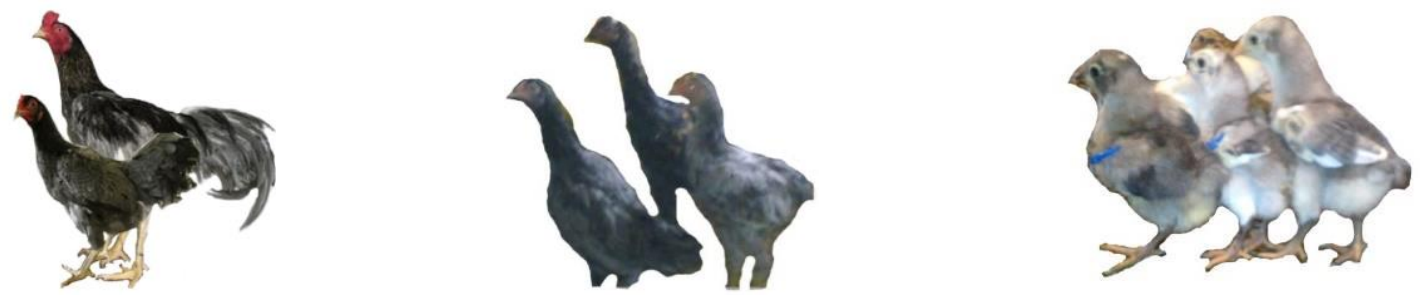

Figure 7. Grey $(\mathrm{G})$ type selected Sentul

Source: Modified version from Hasnelly et al. (2017)
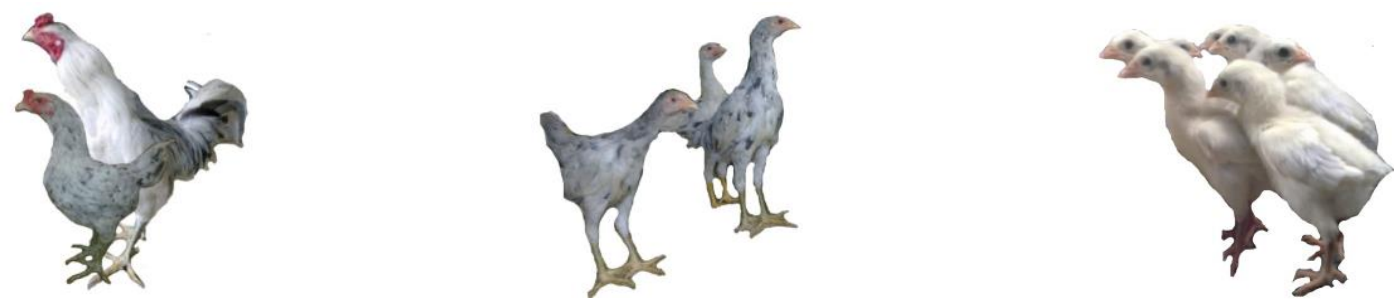

Figure 8. Black spotted white (BSW) selected Sentul

Source: Modified version from Hasnelly et al. (2017)

SenSi-1 Agrinak (Figure 7 and 8). The selection was then continued for six years period by applying the same selection criteria both to $\mathrm{G}$ and BSW type of selected Sentul.

\section{Characteristics of SenSi-1 Agrinak}

After six generation of selection the IRIAP named the product as SenSi-1 Agrinak breed. The breed was then officially registered at the Ministry of Agriculture of the Republic of Indonesia with the registration Number of 39/kpts/pk.020/1/2017, dated of January the $20^{\text {th }} 2017$.

Qualitative and quantitative characteristics of SenSi-1 Agrinak were reported by Hasnelly et al. (2017). Performance of SenSi-1 Agrinak chicken was relatively better than their parents. Commercially expected body weight at 10 weeks of age was achieved, whilst their plumages, which were specifically differentiated from other commercial local chicken, makes clear recognition by ordinary chicken consumers.
Hasnelly et al. (2017) reported that when G type SenSi-1 Agrinak was mated inter-se the offspring had: (1) Grey feather color of $55.51 \%$ in males and $60.77 \%$ in females; (2) Yellow shank color of $52.51 \%$ in males and $33.33 \%$ in females; (3) Pea type comb of $90.98 \%$ in males and $89.23 \%$ in females; and (4). Ten weeks live weight were $886.38 \pm 142.93 \mathrm{~g} / \mathrm{bird}$ in males and $739.17 \pm 118.87$ in females. Inter-se mating of BSW type SenSi-1 Agrinak had their offspring of: (1) BSW feather color of $75.65 \%$ in males and $83.30 \%$ in females; (2) Yellow shank color of $51.91 \%$ in males and $36.59 \%$ in females; (3) Pea type comb of $91.55 \%$ in males and $92.28 \%$ in females; and (4) Ten weeks live weight were $908.76 \pm 130.98 \mathrm{~g} / \mathrm{bird}$ in males and $750.53 \pm 110.56 \mathrm{~g} / \mathrm{bird}$ in females.

Hasnelly et al. (2017) further reported that the shank color distribution of SenSi-1 Agrinak was found to be five colors. The number of color or the frequency $(\%)$, in general was dominated by yellow in the two types of Sensi-1 Agrinak chicken. Black shank was dominated by $\mathrm{G}$ type both male and female. Yin et al. (2001) reported that light color of the shank was 
completely dominant to dark shank color, although according to Liu \& Niu (1994) who stated that the phenotype of chicken shank become more and more complex and the relevant research results differ from each other. However, the variation of the shank color would offer the breeders to further selection based on the preference of the consumers.

Body weight and size of mature males and females SenSi-1 Agrinak both types are presented in Table 2 (Hasnelly et al. 2017). The difference between the two types of SenSi-1 Agrinak was not significant, as expected due to the same selection criteria were applied to both types. The measurement was taken when the birds were assumed to be in the steady phase of growth.

The analysis of the selection response on body live weight of 10 weeks old was reported by Iskandar \& Sartika (2015) who found that the average predicted the response of selection based on differential selection for the G and BSW type SenSi-1 Agrinak males were respectively 25.55 and $30.23 \mathrm{~g} /$ generation, respectively. While their predicted response based on intensity were 37.41 and $40.94 \mathrm{~g} /$ generation, respectively. The response of both types SenSi-1 Agrinak, based on actual response was 43.50 and 38.50 g/generation, respectively. Whilst predicted selection response based on realized response were 55.33 and 55.33 g/generation, respectively for $\mathrm{G}$ and BSW type SenSi-1 Agrinak.

\section{DELIVERY STRATEGY OF SENSI-1 AGRINAK}

The SenSi-1 Agrinak was promoted to private local chicken breeders, to be able to distribute directly to farmer users, throughout Indonesia. The licensing system was applied to the private breeders to overcome insufficient facilities in IRIAP to multiply the chickens. Table 3 shows the list of licensors and their memorandum of understandings in collaboration with IRIAP. The progress of those collaborations was somehow maintained to fulfill the demands of the national local chicken industry. According to Naryanto (2018, Pers. Com.), who is the owner of PT Sumber Unggas Indonesia, unofficially reported that about 5 million of final stock DOC (a hybrid of SenSi-1 Agrinak and KUB-1 chicken) has been prepared to deliver in 2018 .

In addition, the West Java Province Livestock Services has also established the local chicken breeding unit in Majalengka District of West Java Province to preserve and multiply the Sentul chicken (Alam 2005). Recently, the efforts have also been carried out by the Ciamis DAHS by applying long term development program as reported by Isyanto et al. (2017) to Sentul increase the use of Sentul chicken, including possibility the use of SenSi-1 Agrinak by: (1) Making the Sentul chicken production center to anticipate any conflict of interest about land using between Sentul farming and

Table 2. Body live weight and size of 12 months old SenSi-1 Agrinak chicken

\begin{tabular}{|c|c|c|c|c|c|c|c|c|}
\hline \multirow{3}{*}{ Variables } & \multicolumn{4}{|c|}{$\begin{array}{c}\text { Grey }(\mathrm{G}) \\
\text { SenSi-1 Agrinak }\end{array}$} & \multicolumn{4}{|c|}{$\begin{array}{c}\text { Black spotted white (BSW) } \\
\text { SenSi-1 Agrinak }\end{array}$} \\
\hline & \multicolumn{2}{|c|}{ Males } & \multicolumn{2}{|c|}{ Females } & \multicolumn{2}{|c|}{ Males } & \multicolumn{2}{|c|}{ Females } \\
\hline & Average & $\mathrm{CV}(\%)$ & Average & $\mathrm{CV}(\%)$ & Average & $\mathrm{CV}(\%)$ & Average & $\mathrm{CV}(\%)$ \\
\hline Body live weight (g) & 3,050 & 10.60 & 2,033 & 12.42 & 3,191 & 6.88 & 2,200 & 11.58 \\
\hline Beak length (cm) & 28.01 & 18.62 & 30.78 & 12.23 & 36.97 & 7.47 & 29.27 & 10.27 \\
\hline Beak width $(\mathrm{cm})$ & 12.82 & 14.55 & 16.23 & 18.54 & 17.55 & 8.88 & 11.72 & 10.64 \\
\hline Head length $(\mathrm{cm})$ & 48.26 & 11.25 & 45.28 & 8.53 & 51.72 & 5.76 & 40.44 & 9.65 \\
\hline Head width (cm) & 32.91 & 9.14 & 31.64 & 4.35 & 36.21 & 6.49 & 28.11 & 7.48 \\
\hline Neck length $(\mathrm{cm})$ & 16.04 & 9.26 & 12.50 & 4.76 & 15.58 & 6.19 & 12.92 & 6.67 \\
\hline Length of back bone $(\mathrm{cm})$ & 24.19 & 11.98 & 22.58 & 4.60 & 26.94 & 5.12 & 19.88 & 9.78 \\
\hline Chest circumference $(\mathrm{cm})$ & 38.92 & 6.75 & 32.20 & 5.25 & 37.12 & 4.26 & 33.92 & 6.13 \\
\hline Length of sternum (cm) & 14.76 & 10.22 & 17.78 & 4.88 & 22.66 & 6.61 & 15.32 & 8.78 \\
\hline Length of upper thigh $(\mathrm{cm})$ & 12.56 & 7.65 & 10.24 & 8.11 & 12.80 & 4.78 & 11.08 & 6.85 \\
\hline Length of lower thigh $(\mathrm{cm})$ & 14.34 & 8.46 & 12.08 & 5.16 & 15.28 & 5.67 & 12.48 & 6.17 \\
\hline Length shank (cm) & 10.68 & 9.64 & 7.94 & 6.88 & 10.88 & 9.95 & 7.96 & 4.41 \\
\hline
\end{tabular}

Source: Hasnelly et al. (2017) 
Table 3. List of IRIAP's cooperators and agreement letters of non-exclusive for license of multiplying SenSi-1 Agrinak

\begin{tabular}{lc}
\hline \hline Private-sector cooperators & Memorandum of Understanding \\
\hline PT Sumber Unggas Indonesia of Bogor West Java & $663 /$ HM.230/H.5.2/04/2016, on 25/04/2016 \\
Dedi farm of Sukabumi, West Java & $610 /$ H.230/H.5.2/04/2016, on 19/04/2016 \\
PT ISFIN (Integrated Socio Farming Indonesia) of Gunung Kidul, & $757 /$ H.230/H.5.2/05/2016, on 27/05/2016 \\
Yogyakarta & \\
Warso Unggul Gemilang of Bogor, West Java & 1091/HM.230/H.5.2/09/2016, on 07/09/2016 \\
Badan Usaha Milik Tiyuh (BUMT) of Tulang Bawang Barat, Lampung & 570/HM.230/H.5.2/04/2016, on 12/04/2016 \\
DNR farm of Bogor, West Java & 2000/HM.230/H.5.2/09/2016, on 09/09/2016 \\
\hline
\end{tabular}

Source: IRIAP Public Services Division (2017)

settlement; (2) Increasing in the number of holdings of Sentul chicken per farmer via credit scheme program; and (3) Improving technical capacity of farmers in raising Sentul chicken.

In 2017-2018, the Ministry of Agriculture of the Republic of Indonesia through the IAARD, has developed distribution program, called "strata". The first stratum has to build the multiplication centers in seven Agricultural Institute for Assessment of Agricultural Technologies (AIAT). The IRIAP has been assigned to guide the activities, consisting building the breeding facilities and to distribute selected breeds, including SenSi-1 Agrinak chicken. The second stratum is establishing the nuclei and plasm system of production of selected local chicken breeds.

Ministry of Agriculture of the Republic of Indonesia has recently developed the program to distribute selected local chicken breed to the poor families, called BEKERJA (poverty alleviation) through distribution of genetically selected local chicken, including SenSi-1 Agrinak. The BEKERJA program covered almost 60,000 poor families spread out in five districts in West Java Province and one district in West Nusatenggara Province. Those six districts are under the responsibility of IAARD.

The BEKERJA program eventually required about three millions day old chicks to be distributed in year 2018. IRIAP's private collaborator like PT Sumber Unggas Indonesia has been then assigned to supply the day old chicks (DOC).

\section{CONCLUSION}

SenSi-1 Agrinak chicken is one of the IRIAP research products, which was selected from the native Sentul breed from Ciamis District, West Java Province. The Sentul male was selected for 10 weeks body live weight combined with the phenotypic appearance of plumage color and comb type. The criteria were applied in the selection to have specific breed easily recognized by the users. After six generations of selection, the name SenSi-1 Agrinak was given as an improved local chicken breed for meat production in Indonesia.

Licensing system to private local chicken breeders was created to accelerate the production and distribution to the farmer local chicken meat producers. Whilst collaboration with AIATs was pursuit by running the strata program and BEKERJA program to increase and distribute the population throughout Indonesia.

\section{REFERENCES}

Alam IP. 2005. Resistensi ayam lokal Jawa Barat: Ayam Sentul. Dalam: Subandriyo, Diwyanto K, Inounu I, Setiadi B, Zainuddin D, Priyanti A, Handiwirawan E, penyunting. Prosiding Lokakarya Nasional Inovasi Teknologi Pengembangan Ayam Lokal. Semarang, 26 Agustus 2005. Bogor (Indonesia): Puslitbangnak dan Fakultas Peternakan Universitas Diponegoro. hlm. 309-313.

Dana N, Dessie T, van der Waaij LH, Johan AM, van Arendonk JAM. 2010. Morphological features of native chicken populations of Ethiopia. Anim Genet Resour. 46:11-23.

Dirjen PKH. 2017. Statistik peternakan dan kesehatan hewan. Jakarta (Indonesia): Direktorat Jenderal Peternakan dan Kesehatan Hewan, Kementerian Pertanian.

FAO. 2007. The state of the world's animal genetic resources for food and agriculture. Rome (Italy): Commission on Genetic Resources for Food and Agriculture Food and Agriculture Organization of the United Nations.

FAO. 2009. Production systems and poultry genetic resources utilized by small producers in areas of West Java and Central Java, Indonesia. GCP/RAS/228/GER Working Paper No. 11. Rome (Italy): Food and Agriculture Organization of the United Nations.

Gaya LG, Mourão GB, Ferraz JBS, Mattos EC, Costa AMMA, Filho TM, Rosa AF, Felício AM, Eler JP. 2011. Estimates of heritability and genetic correlations for meat quality traits in broilers. Sci Agric. 68:620-625. 
Hasnelly H, Iskandar S, Sartika T. 2017. Qualitative and quantitative characteristics of Sensi-1 Agrinak chicken. JITV. 22:68-79.

Hidayat C, Sopiyana S. 2010. Potensi ayam Sentul sebagai plasma nutfah asli Ciamis Jawa Barat. Wartazoa. 20:190-205.

Hirst KK. 2017. The domestication history of chicken (Gallus domesticus): Who gets the credit for taming the wild jungle fowl? Thoughtco [Internet]. [cited $2018 \mathrm{Apr}$ 20]. Available from: https://www.thoughtco.com/thedomestication-history-of-chickens-170653

Hoffmann I, Scherf B. 2010. Implementing the global plan of action for animal genetic resources. Anim Gen Res. 47:1-10.

Iskandar S, Gunawan B, Resnawati H. 2012. Initiation of selection in Sentul native chicken: Ten weeks of growth rate. In: Wina E, Prasetyo LH, Inounu I, Priyanti A, Anggraeni A, Yulistiani D, Sinurat AP, Situmorang P, Wardhana AH, Dharmayanti NLPI, et al., editors. Technology Innovation in Support of Sustainable Livestock Development and Food Security. Proceedings International Conference on Livestock Production and Veterinary Technology. Bogor, 1-4 October 2012. Bogor (Indonesia): Puslitbangnak. p. 35-39.

Iskandar S, Sartika T. 2015. Selection for 10 weeks old bodyweight on Sentul chicken. In: Integrated Approach in Developing Sustainable Tropical Animal Production. The 6th International Seminar on Tropical Animal Production. Yogyakarta, 20-22 October 2015. Yogyakarta (Indonesia): Faculty of Animal Science, Gadjah Mada University, Indonesian Society for Sustainable Tropical Animal Production. p. 387-390.

Isyanto AG, Sudrajat, Iskandar M. 2017. Strategi pengembangan ayam Sentul di Kabupaten Ciamis. J Pemikiran Masyarakat Ilmiah Berwawasan Agribisnis. $3: 1-12$.

Jaturasitha S, Leangwunta V, Leotaragul A, Phongphaew A, Apichartsrungkoon T, Simasathitkul N, Vearasilp T, Worachai L, ter Meulen U. 2002. A Comparative study of Thai native chicken and broiler on productive performance, carcass and meat quality. In: Conference on International Agricultural Research for Development. Kassel (Germany): Kassel University Press. p. 1-9.

Jin S, Lee JH, Seo DW, Cahyadi M, Choi NR, Heo KN, Jo C, Park HB. 2016. A major locus for quantitatively measured shank skin color traits in Korean native chicken. Asian-Australas J Anim Sci. 29:11:15551561.

Liu FZ, Niu ZY. 1994. Preliminary study on the genetics of feather color and skin color in Lueyang chicken. J Yellow Cattl Sci. 20:29-30.

Morejohn G V. 1968. Study of plumage of four species of the genus Gallus. Condor. 70:56-65.
Nishida T, Hayashi Y, Nozawa K, Hashiguchi T, Mansjoer SS. 1988. Morphological studies on the Indonesian native chicken. Japan J Zootech. 59:1047-1058.

Nishida T, Nozawa K, Hayashi Y, Hashiguchi T, Mansjoer SS. 1982. Body measurement and anlysis of external genetic characters of Indonesian native fowl. The origin and phylogeny of Indonesian native livestock. Res Gr Overseas Sci Surv Rep. 3:73-83.

de Paiva JT, Murao GB, Ferraz JBS, Mattos EC, Filho TM, Campos BM, Eler JP, Gaya LG. 2018. Inferences on the effects of selection for feed conversion over meat quality traits in broiler. Sci Agric. 75:129-135.

Purba R. 2016. Ini alasan bisnis ayam Kampung menjanjikan. Kompasiana [Internet]. [disitasi 3 Februari 2017]. Tersedia dari: http://www.kompasiana.com/febroni purba/ini-alasan-bisnis-ayam-kampung-menjanjikan_ 5751026af17a61d905899be8

Rasyid TG, Kasim SN. 2014. Analisis pendapatan usaha peternakan ayam buras pedaging di Desa Bungungloe Kecamatan Turatea, Kabupaten Jeneponto. JIIP. 1:158-167.

Sarker NR, Hoque A, Faruque S, Islam N, Bhuiyan FH. 2014 An $e x$ situ study on body characteristics and effect of plumage color on body weight of natives chicken (Gallus domesticus) in Bangladesh. Acta Sci Anim Sci. 36:79-84.

Sarsenbek A, Wang T, Zhao JK, Jiang W. 2013. Comparison of carcass yields and meat quality between BaichengYou chickens and Arbor Acres broilers. Poult Sci. 92:2776-2782.

Sartika T, Iskandar S. 2007. Mengenal plasma nutfah ayam Indonesia dan pemanfaatannya. Bogor (Indonesia): Balai Penelitian Ternak.

Sartika T, Iskandar S, Prasetyo LH, Takahashi H, Mitsuru M. 2004. Kekerabatan genetik ayam Kampung, Pelung, Sentul dan Kedu Hitam dengan menggunakan penanda DNA mikrosatelit: I. Grup pemetaan pada makro chromosom. JITV. 9:81-86.

Sartika T, Iskandar S, Tiessnamurti B. 2017. Sumberdaya genetik ayam lokal Indonesia dan prospek pengembangannya. Jakarta (Indonesia): IAARD Press.

Sartika T, Sopiyana S, Iskandar S. 2010. Performans ayam Sentul koleksi ex situ di Balai Peneltian Ternak. Dalam: Pengembangan Peternakan Berkelanjutan: Sistem Produksi Berbasis Ekosistem Lokal. Prosiding Seminar Nasional Peternakan Berkelanjutan ke-2. Jatinangor, 3-4 November 2010. Jatinangor (Indonesia): Fakultas Peternakan Universitas Padjadjaran. hlm. 39-51.

Sawai H, Kim HL, Kuno K, Suzuki S, Gotoh H, Takada M, Takahata N, Satta YY, Akishinonomiya F. 2010. The origin and genetic variation of domestic chickens with special reference to jungle fowls Gallus g. gallus and G. varius. PLoS One. 5:1-11. 
Sejati KW, Saptana. 2013. Analisis manajemen rantai pasok ayam Kampung pedaging: Studi kasus di Provinsi Jawa Barat dan Jawa Timur. Bogor (Indonesia): Pusat Sosial Ekonomi dan Kebijakan Pertanian.

Suherman DS. 2015. Disnak Ciamis bangun pembibitan ayam buras Sentul. Harapan Rakyat [Internet]. [disitasi 6 Februari 2018]. Tersedia dari: http://www.harapanrakyat.com/2015/10/disnakciamis-bangun-balai-pembibitan-ayam-buras-sentul/

Sulandari S, Zein MSA, Paryanti S, Sartika T, Sidadolog JHP, Astuti M, Widjastuti T, Sujana E, Darana S, Setiawan I, et al. 2007. Keanekaragaman sumber hayati ayam lokal Indonesia: Manfaat dan potensi. Bogor (Indonesia): Pusat Penelitian Biologi LIPI.

Sulandari S, Zein MSA, Sartika T. 2008. Molecular characterization of Indonesian indigenous chickens based on mitochondrial DNA Displacement (D)-loop sequences. Hayati. 15:145-154.
Umaya SR. 2014. The uniqueness of immune competence and meat quality of native chickens: A specialized review. World J Pharm Sci. 3:2576-2588.

Wibowo B, Sartika T. 2011. Analisis kelayakan usaha penggemukan ayam kampung (lokal) di tingkat petani studi kasus kelompok peternak ayam kampung "Barokah" di Ciamis. Dalam: Prasetyo LH, Damayanti R, Iskandar S, Herawati T, Priyanto D, Puastuti P, Anggraeni A, Tarigan S, Wardhana AH, Dharmayanti NLPI, penyunting. Teknologi Peternakan dan Veteriner untuk Peningkatan Produksi dan Antisipatif terhadap dampak Perubahan Iklim. Prosiding Seminar Nasional Teknologi Peternakan dan Veteriner. Bogor, 7-8 Juni 2011. Bogor (Indonesia): Puslitbangnak. hlm. 699-704.

Yin HG, Zeng ZJ, Pan YM, Zhou KY. 2001. The genetic expression of dark shank in chicken. Sichuan Anim Vet Sci. 28:17-18. 